Article

\title{
The Sharing Economy and Sustainability of Urban Destinations in the (Over)tourism Context: The Social Capital Theory Perspective
}

\author{
Piotr Zmyślony ${ }^{1, *}$, Grzegorz Leszczyński ${ }^{2}$, Anna Waligóra ${ }^{3}\left[\right.$ and Wiesław Alejziak ${ }^{4}$ (i) \\ 1 Department of International Economics, Poznan University of Economics and Business, aleja Niepodległości \\ 10, 61-875 Poznań, Poland \\ 2 Department of Marketing Strategies, Poznan University of Economics and Business, aleja Niepodległości 10, \\ 61-875 Poznań, Poland; grzegorz.leszczynski@ue.poznan.pl \\ 3 Department of Sociology and Business Ethics, Poznan University of Economics and Business, aleja \\ Niepodległości 10, 61-875 Poznań, Poland; anna.waligora@ue.poznan.pl \\ 4 Institute of Entrepreneurship and Management, Faculty of Tourism and Recreation, University of Physical \\ Education in Krakow, aleja Jana Pawła II 78, 31-571 Kraków, Poland; wieslaw.alejziak@awf.krakow.pl \\ * Correspondence: piotr.zmyslony@ue.poznan.pl
}

Received: 31 January 2020; Accepted: 14 March 2020; Published: 16 March 2020

\begin{abstract}
This article contributes to the discussion on the sustainability of the sharing economy by adopting the Social Capital Theory to expand explanations of the sharing economy's role and scope of relations with local communities in the context of overtourism. As mutual relationships have not been fully recognized through a theoretical perspective, the article aims to examine the sustainability of the process of the sharing economy impacting urban tourism communities in light of Robert Putnam's approach to Social Capital Theory. On the basis of a selective systematic review, the article discusses the sustainability of the sharing economy through the lens of bridging and bonding social capital. We argue that a new configuration of social capital, i.e., a sharing platform-modified social capital, arises from the unsustainable and disruptive power of the sharing economy implemented by virtual platforms, thereby contributing to an overtourism syndrome. However, from a medium- and long-term perspective, the sharing economy also impacts the bridging nature of social capital, which should lead to a more sustainable balance in its structure. This initial framework for understanding the impact of the sharing economy on sustainability of local communities provides an alternative approach to studying residents' perceptions and attitudes towards tourism in the areas affected by overtourism.
\end{abstract}

Keywords: sustainability; sustainable development; Social Capital Theory; sharing economy; collaborative economy; overtourism; tourism; urban tourism; gentrification; tourism impact

\section{Introduction}

The so-called sharing economy (SE) and overtourism are both coincidental and complementary phenomena. Since they have been simultaneously experienced by communities in the growing number of, mainly urban, destinations, academic studies as well as industry-related and governmental insights associate or join them together as disruptive, unsustainable forces undermining long-term tourism development and community well-being [1-10]. This recent wave of research has complemented the existing discussion on the sustainability of SE [11-15].

Nevertheless, although complementary, both phenomena are of a different nature and scope. SE refers strictly to social relations which are embedded in and also fuel and transmit social capital [16-18]. Accelerated by technological development, it develops globally and transforms even more spheres of 
human and economic activity, strongly emphasizing its presence in the tourism industry, especially in accommodation, transport, catering and tourism experiences $[19,20]$. As the SE's impact is widely discussed through the prism of accommodation platforms [20-23] we mostly consider this sector of the tourism industry. Overtourism, in turn, is a place-specific and industry-related mechanism. As a temporary and 'explosive' phenomenon, it condenses all the aspects of visitors' activity and the tourism industry in affected destinations, including the experiences or services distributed or accessed by sharing. Thus, when these two phenomena are studied together, we can discuss tourism as a domain of the SE, and the 'sharing' aspects of overtourism.

Yet, due to an early phase of their evolution and the eruptive nature of their expansion, mutual relationships of both phenomena have not been fully recognized, leaving a gap for further research. Even so, many researchers claim that the SE contributes to overtourism by jointly pushing urban gentrification processes, depopulation of city centers and other processes of social exclusion [3,24-28]. In light of this, in this article we consider overtourism in the context of studying the impact of the SE expansion on local communities. The emerging overtourism syndrome may be one of first striking examples of the problems in which the SE is directly involved. Thus, the externalities resulting from the SE in (over)tourism context on the community level could be a laboratory for SE's influence in general.

Although sustainability issues involving the SE have been discussed quite often in the tourism development context $[1,24,26,29]$, these studies were contextual, based on the case studies, and also related to various conceptual frameworks(or none, if not indicated by the authors). The majority of them identify and characterize the positive/negative impact of the SE on local communities by referring to respondents' opinions or figures indicating a certain stage or level of the phenomenon $[3,4,30,31]$. Theoretical studies investigating the process of the SE impact itself through the prism of concrete theoretical frameworks can hardly be found. Apart from the Social Exchange Theory (SET) [28], which is frequently utilized as a field research framework, the presence of other theories is very limited [32,33]. Thus, there is a need for conceptual studies which could explain the links between sustainability and the SE impact on the local communities in the tourism context in a complex way, framed by a clearly-defined theory which goes beyond tourism-specific concepts.

This viewpoint article addresses the gap in the theoretical discussion on the expansion of the $\mathrm{SE}$ in the urban communities affected by overtourism. As the SE refers to social relations, and well-being and quality of life are recognized as crucial indicators of the social dimension of sustainable development [34,35], the article aims to conceptualize the impact of the SE on urban destinations through the lens of Putnam's $[18,36]$ approach to Social Capital Theory (SCT). However, both the SE and overtourism affect the density of social capital, thereby triggering calls for sustainable solutions. Discussing the impact of the SE on local communities in the tourism context would allow us to compare the prevailing discussion on the sustainability of the SE and propose a new perspective for interpretation and research on the subject. Thus, we argue that the SCT contributes to gaining a more complete picture of the conjunction of the SE, overtourism and a local community's (un)sustainable development.

The article contributes to the discussion on sustainability of the SE by adopting the SCT framework to expand explanations on in its role and scope of impact on local communities in relation to the overtourism syndrome. As the tourism industry is one of the spheres where the $\mathrm{SE}$ is diffusing, and it is estimated to expand into other market and social activities $[7,13,20,37]$, one can argue that the overtourism context should be considered as a laboratory for studying the sustainability of its impacts in general. The article also contributes to the discussion on overtourism by focusing on the impact of the SE on local communities, instead of only identifying the effects of these changes.

The latter parts of the article are organized as follows. First, we explain the method applied. Then, the SE is briefly introduced in the sustainability and the tourism contexts. After that, we focus on the relations between overtourism and the SE. Next, the review of the sustainability of the SE in the tourism context is presented. The following part discusses the principles and the evolution of the SCT. In the results section, we juxtapose the literature review results concerning the sustainability of the SE 
with the SCT perspective. We conclude by implementing a new configuration of social capital and its consequences for local communities in the context of overtourism.

\section{Materials and Methods}

Our considerations are based on a review of the existing literature on the subject. We adopted a two-step selective systematic review of the papers indexed in Web of Science and Scopus databases. It the first step, we conducted two separate procedures focusing on search terms 'overtourism'; and 'sharing economy' or 'collaborative consumption' indicated in the article titles, abstracts or keywords. The aim of the analysis was to recognize their definition range and the main research threads referring to both phenomena. No year limit was used. Because of the research aim and the large number of document results (98 records referring to overtourism and 2135 records referring to the sharing economy), we limited the review to the most frequently cited documents.

In the second step, we focused on the articles referring to overtourism/tourism development and the SE, both referring to sustainability. Thus, the following search terms were selected: 'overtourism' or 'tourism'; 'sharing economy' or 'collaborative consumption'; and 'sustainability' or 'sustainable development'. The search resulted in 25 documents. The selection procedure consisted of initial scanning in line with the criteria used in the second step. Moreover, the specification of the theoretical/conceptual framework of the study was an additional criterium. In effect, nine papers were omitted. The organized final list of selected 16 papers is specified in Appendix A. The review focused on an analysis of the content of each paper in order to synthesize different perspectives and identify the scope of the SE impact on the sustainability of local communities.

The selected papers were published in the years 2016-2019. They refer to various theoretical frameworks and concepts. Indeed, the Social Exchange Theory proved to be the most popular concept [3,28,38,39], in combination with neoclassical economics [32]. However, besides a single paper designed as a theoretical dispute on the regulation of the SE, they all use the theory for empirical reasons such as to measure residents' perceptions, and not to recognize the links between the SE and communities. According to SET, the attitude of the residents relies on the assessment "of the expected benefits or costs obtained in return for the services they supply". In general, the residents will support the development of a phenomenon or activity, if they perceive more positive impacts (benefits) than negative impacts (cost) from it [40]. The Social Representation Theory is an alternative concept, applied by von der Heidt et al. [31]. It refers to a system of symbolic representations-which could be conceptualised as "a history of mentalities" instead of objective reality-shared both by individuals and society. This system is the foundation of the individuals' building their perception of one's self as a part of a group [41]. The other works are based on tourism-specific concepts: tourism degrowth theories [42], the social carrying capacity concept [4], Doxey's [43] Irridex model and Butler's [44] Tourism Areal Life Cycle Model. Alternatively, they design their own research frameworks [25,30,45]. Two literature reviews conclude the set of literature.

Moreover, in the conclusion part, we used more general literature referring to both tourism development and social capital. A literature review on overtourism and the SE points to some attempts to recognize the relations between the SE and on local communities; however, it is performed without any reference to social capital. As social capital is the key adhesive of communities, we argue that it should be included in this discussion to gain a more complete picture of the conjunction of the SE, overtourism and local community (un)sustainable development.

\section{The Sharing Economy Interplay with Sustainability}

There is no agreement among scholars about what the SE is and how it refers to other types of modern forms of economic models $[19,46,47]$. In its narrow and primary meaning, the SE refers to the short-term use of less-frequently used assets by various actors within a network economy, enabled by the development of the Information and Communication Technologies (ICT). Nowadays, the SE 
has encompassed a variety of different products and services, which are distributed or accessed to by sharing or through collaborative practices [48].

Having in mind terminological controversies, the variety of the SE concepts and related terms [19,20,49], we follow Acquier et al. [50] and Netter at al. [48] to adopt a broad understanding of the SE term. We consider the SE as an umbrella construct that encompasses business-to-business, business-to-consumer and peer-to-peer initiatives-driven both for-profit and non-profit motivations-which are based on and combine at least three following foundation cores [50]: (1) the platform economy, in terms of intermediating decentralised exchanges among peers through digital platforms; (2) the access economy, in terms of sharing under-utilized assets to optimize their use, offering services instead of products; (3) the community-based economy, in terms of coordinating initiatives through non-contractual, non-hierarchical or non-monetized forms of interaction. We elaborate on each of these cores below.

The SE networks are strictly associated with digital technologies, which are both a driver towards and the essence of the SE [51-54]. The ICT has made sharing convenient and transparent as well as open to many individuals and businesses, regardless of their size and location. The term "platform" refers to an intermediary acting to create access or to manage exchanges, payments and evaluations among peers or companies [13]. The platforms are the structures which enable transactions by connecting two contracting parties for the purchase of commodities or the provision of services [55].

The SE is rooted in social relations, as the access economy and the community-based economy are among the foundation cores of the SE. Thus, the issue of its sustainability in general (not only in the tourism context) has been raised as a characteristic of the SE phenomenon. Originally, the $\mathrm{SE}$ has been popularized as a more sustainable form of consumption [56-58]. However, with the development and proliferation of the SE models and platforms, the debate around their impacts on sustainability has been growing and critical voices have become more sound [13,47,50,59,60]. Moreover, because of the newness of the SE concept, descriptive and explanatory studies dominated literature and report reviews $[1,12,37,61-63]$ or the internet and social media monitoring [13], supplemented by research projects based on the primary sources analysis and case studies of selected industries or platforms $[33,56,64,65]$. On the basis of the transition theory, Martin [15] claims that the SE can have positive impacts on sustainability because it creates economic opportunities, but it can also increase unsustainability by reinforcing the forms of neoliberal capitalism. Similarly, Geissinger et al. [13] stress that sustainability impact of the SE is hard to operationalize and measure objectively because of the ambiguous and diverse nature of the SE. This fact allows some marketers of the SE platforms to conduct 'share-washing' of their activities on official and social media [13,61].

Because of its specific characteristics and systemic problems-in particular, its functioning in the global-local nexus [66-68] - tourism is an industry that is particularly exposed to sharing practices $[19,20,47,69]$. Dredge and Gyimóthy [19] identify the existing collaborative opportunities in the food, travel services, health and wellness, currency exchange, travel companions and support, accommodation and work space, transport and education industries. Based on the object of exchange, Gössling and Hall [20] grouped the sharing market in tourism into three building blocks: asset, services and opinion. They refer to accommodation, transport, food, information, advice and evaluation, travel visualization, virtual travel and advocacy. Their common characteristic is the exchange process being facilitated by an app or website intermediary. Palgan et. al. [70] classify the sharing platforms operating in accommodation industry according to a type of exchange. They distinguish between a commercial exchange (business-to-customer exchanges), rental (peer-to-peer flats rented directly from owners or managed as timeshares), reciprocal exchanges (home swaps) and free accommodation (guests are accommodated without commercial interest). However, Airbnb is the most eminent and discussed example of the sharing economy business model in tourism, which has changed the global value chain's logic and has become a symbol of the disruptive power of the global economy and local communities living in popular tourism destinations $[21,69,71-73]$. As the impact of the SE on the 
accommodation sector has opened the widest and the most lively discussion among scholars [20-23], our considerations refer mostly to this area of the tourism industry.

\section{Overtourism as a Context of the SE's Impact}

Overtourism is a recent syndrome experienced in a growing number of destinations, prominently affecting towns and city centers with well-known cultural assets and popular amenities [26,29,74,75]. Milano et al. [76] define it as the excessive growth of visitors leading to overcrowding in areas where residents suffer the consequences of temporary and seasonal tourism peaks, which have enforced permanent changes to their lifestyles, access to amenities and general well-being. In a narrow context, overtourism refers to the physical characteristics of cities and is just about managing tourist flows to stop them from increasing above the maximum carrying capacity thresholds in time and space, in central or in historic quarters. However, its complex and disruptive nature has led researchers and governance practitioners to perceive overtourism in a wider context and through a more sophisticated lens. Goodwin [77] notes that the destinations experience overtourism not only when "hosts or guests, locals or visitors, feel that there are too many visitors", but also when they feel "that the quality of life in the area or the quality of the experience has deteriorated unacceptably". Koens et al. [26] coined a much more comprehensive definition, specifying that overtourism is "an accumulation of different impacts and perceptions that relate both to tourist behavior as well as actions by, and encounters with stakeholders as well as changes to the social, economic and physical environment" (p.5). In this wider meaning, overtourism refers not only to the tourist number, but to the wide range of over-developed tourism impacts, including supply side and boosterism policies based on tourism functions. Thus, it is the quality of the residents' life which is at stake in the overtourism struggle, discussed in the literature in the wider context of sustainability $[45,77,78]$.

Resultantly, calls for mitigating the negative consequences, conflict management, more sustainable tourism development strategies or even degrowth proposals have been raised in tourism academic discourse [79-81]. Nevertheless, researchers stress that overtourism as a destination-specific phenomenon is resistant to "one-size-fits-all" solutions [26,77].

In general, the changes which effect overtourism and the sharing economy are generated by various megatrends [82]. It is the cities where the strongest intensity and impact of the megatrends on tourism can be observed. In particular, it refers to the factors evoked by both the technological (eg. digital transformation) and economic megatrends (eg. globalisation) [83,84]. Despite complex, multifaceted and dynamic nature of both phenomena that makes them slip out of clear definitions and objective measurement, we can state that overtourism and the SE are complementary phenomena (Appendix A). As tourism is a spatially-concentrated phenomenon-as evidenced sharply in the destinations affected by overtourism - the impacts of the SE, also an uneven dispersal activity at the community level areas are one of the most frequently discussed topics in relation to the development of tourism. Researchers mostly agree that the relationship between overtourism and the SE is not only spatial; this relationship is also causal. However, the academic papers can be divided into three perspectives of that causality (see Table 1). The first one consists of works which consider the SE as an enabler or component of overtourism, i.e., as a factor contributing to overtourism. In this context, the SE is perceived in an oversimplified way, contributing to selected dimensions of overtourism defined in a wider meaning or accelerating them, like the spatial saturation of overtourism, the shortage of available living space and the increase in rents. The soundest thread of the studies in this perspective deals with the measuring of residents' perceived impacts of overtourism and/or the proliferation of the SE and their attitudes towards tourism and the tourists associated with these impacts. The second perspective presents a two-way nature of relationships, indicating that both phenomena are not only coincidental but also fueled by a feedback loop mechanism, leading to a more comprehensive phenomenon, i.e., gentrification. The third perspective, which deals with the SE as an effect of overtourism, is not strongly represented in the literature. The studies link overtourism to a growing number of tourists or international party-goers, fueling the expansion of non-institutionalized 
forms of tourist accommodation. Nevertheless, there are also studies which do not fit in only one category as they take a multi-view approach. Additionally, there are papers which present literature overviews of the existing approaches and concepts on the subject.

Table 1. Perspectives of the sharing economy (SE)—overtourism relationship.

\begin{tabular}{|c|c|}
\hline Dimension & SE Perceived/Studied as \\
\hline The SE contributing to overtourism & $\begin{array}{c}\text { The SE as a cause of overtourism }[77,80,85-87] \\
\text { The SE as a factor of consolidating/speeding overtourism }[29,42] \\
\text { Making use of private accommodation as a consumer authenticity } \\
\text { and localhood trend }[26,29,47,77,88-90] \\
\text { Proliferation of the SE accommodation as a factor leading to } \\
\text { deterioration of residents' perception/attitudes towards } \\
\text { tourism/tourists }[2,3,28,31,80]\end{array}$ \\
\hline The SE collating overtourism & $\begin{array}{c}\text { The SE and overtourism accommodation as inter-fueled factors of } \\
\text { gentrification }[26,45,74,85,89,91] \\
\text { Additional facets of residents' annoyance and potential local } \\
\text { conflicts }[27,45,92]\end{array}$ \\
\hline The SE resulting from overtourism & $\begin{array}{c}\text { The SE proliferation as an outcome of exceeding tourist numbers [74] } \\
\text { The SE as an outcome of a growing number of night-time } \\
\text { party-goers [91] }\end{array}$ \\
\hline
\end{tabular}

Due to the multidimensional nature of both phenomena, and their early level of evolution, it is hard to verify the validity of classifications presented in Table 1. Consequently, it is necessary to adopt one of these three perspectives to carry on with considerations by allowing for a more in-depth study of the phenomenon. Therefore, taking the above into account, this article adopts the second perspective, although it is not the most frequently used one. First, this approach partially overlaps with the first one, implying a much broader range of consequences. We perceive the SE as being rooted in the social relations among individuals and within neighborhoods and, thus, as being endowed with the ability to leave a deeper and longer lasting mark on communities which could not be easily-if there is any easy issue at all in the overtourism syndrome-mitigated or inverted. Second, the SE is a trend that is not only spreading in tourism, as this industry could just be a transfer platform to other sharable and collaborative activities. In this context, we situate our article in a sociologic study, adopting the city as a spatial scope of research, and tourism as a research context within the dynamic framework of overtourism in which social relations occur and social capital is changing.

\section{The Sharing Economy and the Sustainability of Local Communities in the Overtourism Context: the Literature Overview}

Focusing on the global tourism industry, Gössling and Hall [20] analyze the sustainable impacts of the SE. Focusing on economic sustainability, the authors emphasize that the platforms facilitate opportunities for individuals and firms to contribute to the economy, and thus they empower small firms and micro-entrepreneurs, who run start-ups with limited marketing resources. They also create innovations and new jobs and thus foster value chains. However, market concentration, rating and ranking dependencies increasing economic inequality between competitors and revenue concentration by platforms are all evidence of the negative impact on sustainability in the context of global tourism.

The sustainability of the SE at the destination/community level is discussed with reference to social, economic and environment domains of sustainability [93]. This is reflected in our literature overview presented in Table 2. (the issues are listed according to the descending number of indications and importance). The social and economic focus dominates, which results from the dominance of the studies focused on residents' perception and attitude measurements. In fact, pursuant to the sustainable development assumption that the development should proceed in line with the needs of the current generations while maintaining the present conditions and opportunities also for the 
future generations, local residents must be recognized as one of the main stakeholders of the process of tourism development, and their well-being and quality of life as the crucial indicator of this development $[34,35,94,95]$. Thus, the resident negative perceptions of and attitudes towards the SE are interpreted as a manifestation of unsustainability, and the positive opinions and reactions to the SE as a manifestation of its sustainability.

Table 2. The impact of the SE on the sustainability of local communities in the tourism context.

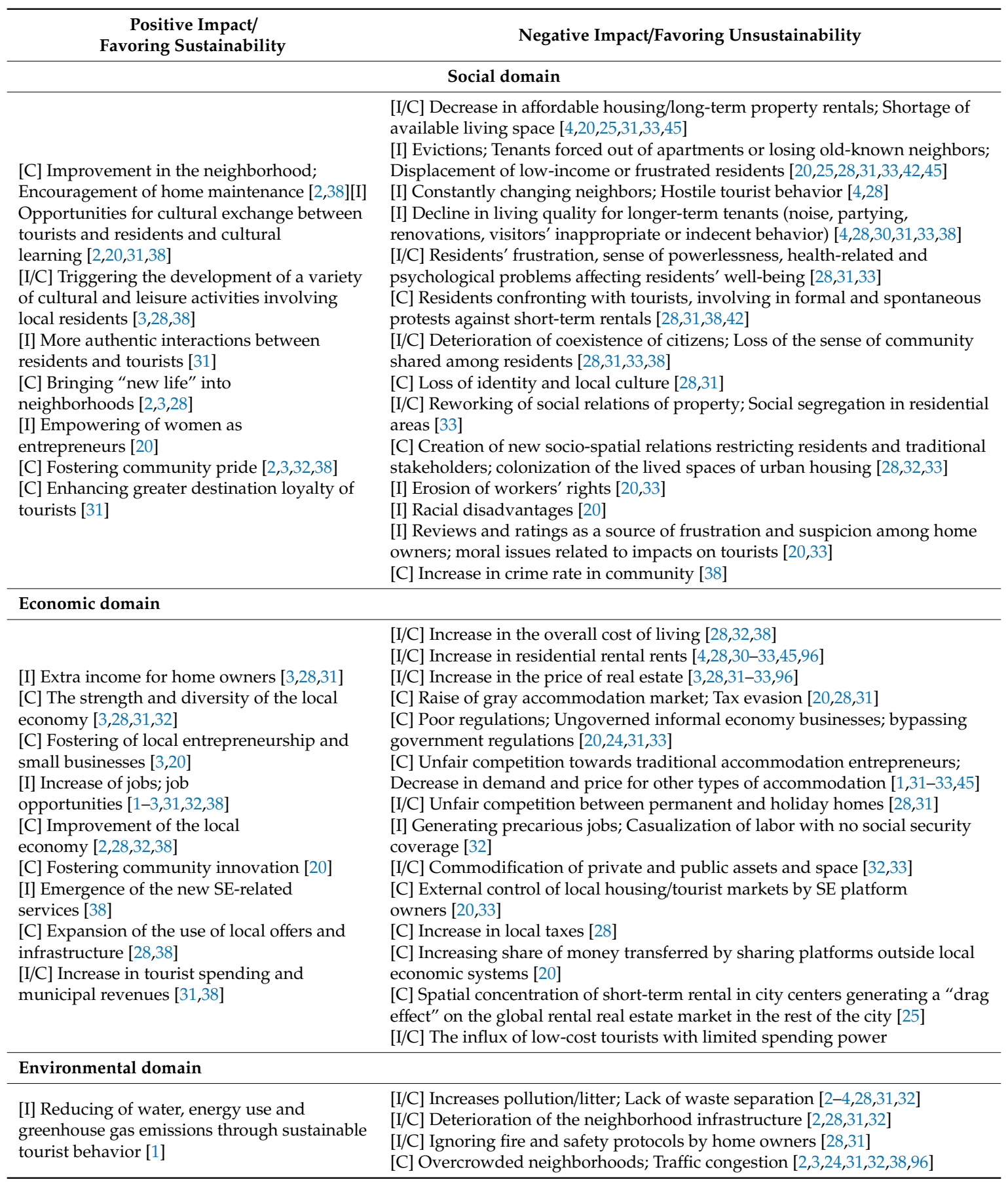

Notes: [I] Perceived by individual residents; [C] Perceived on the community level; [I/C] Perceived on both levels.

Source: own elaboration based on review of papers listed in Appendix A.

The studies focusing on the resident perceptions recognize the SE as the main subject scope $[2,38,39]$ or as a dimension of excessive tourism development $[3,42]$. Although the general residents' attitudes 
towards the SE could vary in specific destinations-for example, the predominance of positive attitudes in Majorka, Spain [2] and the USA [38] vs. the predominance of negative attitudes in Barcelona, Spain [31] and Byron Bay, Australia [31] was identified - the juxtaposing of all the reviewed studies indicates the dominance of unsustainable impacts of the SE (Table 2.). The most frequently raised issue refers to the interference of exponential and ungoverned growth of informal peer-to-peer accommodation on local residents' lives and the costs thereof. In particular, its disruptive role is perceived mainly by individuals who are not directly engaged in gaining from the SE. Nevertheless, many of the problems have become common issues, with repercussions affecting communities in general. As Stergiou and Farmaki [28] note, in residential areas, tourism-associated impacts are particularly concerning because the micro-level of neighborhoods represents the basis of societal structures and processes. For example, housing issues in terms of a shortage of long-term rentals, raising rents and replacements, as well as the lowering of the quality of living are perceived by individual residents; however, their increasing frequency affects neighborhoods and communities. Also, the long-term and commonly shared loss of community sense, identity and local culture has been recognized. Among the economic impacts, high residential rents and real-estate prices, the increasing of gray market and tax evasion as well as unfair competition has been identified.

The sustainability of the SE has also been identified, especially in terms of enlivening and enhancing the aesthetics of neighborhoods, cultural impacts, extra incomes of home owners as well as fostering entrepreneurship and innovation among residents. The environmental issues have also been recognized and their impacts are controversial.

Three issues must be raised while referring to Table 2. First, impacts evidencing both sustainability or unsustainability of the SE are interconnected. They are not perceived seperately; instead these issues usually form a bundle of impacts propelling each other, forming a dynamic of interactions among the SE, local communities as destinations, and the tourism growth, which may fuel overtourism. For example, there are causality links amongst more income for home owners, improvement in neighborhoods, increase of residential rental rates, displacement of tenants, commodification of private and public assets and local resistance. Thus, Table 2 is composed from many 'sustainability pictures' of the SE rather than just one. Second, some impacts could be contradictory or mutually debilitating. This could be an issue involving the authenticity of resident-visitor relationships while raising the sense of powerlessness of the latter, or increasing the number of jobs which are precarious and casual. However, Table 2 is a composition of findings of the theoretical and research studies which are fragmentary, contextual or based on the case studies. Third, the general picture of (un)sustainability of the SE impacts on local communities in tourism context lacks dynamic overview. The majority of the studies-for objective reasons-diagnose the status of the impacts of the SE using selected aspects of the process. In other words, they mostly deliver static pictures of the process based on opinions of residents and key stakeholders or geostatistical data.

Given above the above arguments together, we must mention two studies which try to explore the mechanism of the process framed by using clearly defined theoretical frameworks which go beyond the tourism-specific concepts.

Stabrowski [33] recognizes sophisticated impacts of the SE on urban communities, which are incorporated in mechanism resulting from business models of sharing platforms. Basing on the Lefèbvre's production of space concept and performativity in economics, the author points out the disruptive role of the reputation system of Airbnb and other accommodation rental platforms, consisting of mutual verification and rating of guests and hosts. However, this rating/reputation is also the only basis for building trust between peers and assessing the quality of their performance on the sharing market, becoming a form of currency in the global sharing system. Notably, it only permits the opinions of peers, restricting local stakeholders like tenants, neighbors or landlords. As the result, as Stabrowski [33] state: "hosts and guests are interpellated as fully autonomous individuals - unburdened by the collective nature of the lived spaces of urban housing-negotiating the rental price of an accommodation that itself is constituted as a bounded spatial entity whose 
use rights are defined in absolute terms. Socio-spatial relations outside of the binary host-guest relation-such as those between or residents within multi-family buildings, between neighbors within an urban locality (neighborhood), or even among the wider urban housing market—are thus 'bracketed out' in this process, with profound implications for public urban space" (p. 336). Surrounding spaces are not free from this impact. The new geographies have been created within cities which colonize the lived spaces of urban housing and public space, imposing global market rules and unbalancing local communities.

Stergiou and Farmaki [28] examine perceptions of residents of Athen's Koukaki residential area regarding the impact of Airbnb accommodation growth on their neighborhood in relation to the exchange relationship with guests. Based on the SET analytical framework, the authors conducted analysis of the full process of resident-guest interactions, dividing it into three steps: initiation of exchange, exchange formation, and overall post-exchange; which lets us look inside the dynamics of the process. In general, the authors state that imposed costs outweighed any positive outcomes brought about by Airbnb and their interactions with guests in their neighborhood and residential environment. However, more positive views came from those participants indirectly engaged in hosting Airbnb guests. According to the detailed results, the residents were imposed to the disruptive face of the sharing accommodation model before the first guests appeared. The disturbance was caused by renovations and refurbishments of apartments, unexpected evictions and losing neighbors, increasing rents and the lack of consultation on the changes. During the exchange formation stage, the negative issues ranged from the presence and rotation of unfamiliar people, intrusion of tourists and commercial activity in the private life and spaces of residents, noise and litter, lessening of community bonds, to problematic issues such as rude and indecent behavior from tourists, damage in communal areas, disputes and occasional open hostility from guests. During the post-exchange evaluation, the residents reported annoyance, irritation, a sense of powerlessness or even fear and health-related and psychological problems affecting their well-being and inducing reactions such as confronting tourists, involvement in formal actions against short-term rentals, resigned acceptance or an interest in moving out of the area. Only residents indirectly involved in Airbnb activities enhanced their efforts to capitalize on opportunities from this activity. Summing up, the mentioned studies focus on a variety of aspects involving the sustainability of the SE on tourism, leading to a fragmented and vague picture with prevailing evaluative aspects. However, there is a need for studies which will provide a complex, theoretical explanation of the relations between the SE and local communities in the tourism context. As existing findings show, different aspects of socio-economic relations should be considered together. We tend to consider: individual relations (between neighborhood and tourists), business relations (between hosts and tourists), inter-institutional relations (between economic and social needs of local and external actors) and macro-process relations (between SE platforms that play the role of moderating the economic and social world and both local communities and authorities that represent them). Supposing that those issues should be framed by a clearly defined theory which goes beyond tourism-specific concepts, we employ the Social Capital Theory because it refers to key social and economic aspects of relationships.

\section{Social Capital as the Reference Point for Communities}

In the context of modern democracy and dynamically changing market conditions [97], social capital is an essential reference point for actions within communities. Therefore, the Social Capital Theory seems to be the most suitable one to illustrate the dynamics of social behavior in relation to emerging social-economic phenomena, including the SE. The SCT encompasses several theoretical trends formed in the second half of the 20th century and still used today. Initially, the significance of social capital has not been spotted, it has been rather discovered gradually starting with the works of Bourdieu $[16,98]$ who is considered to be the creator of the narrative focused on the relationships in the community. His theory of "dark" social capital mainly refers to the social inequalities caused by access to goods such as education. According to the theory, a high level of social capital (e.g., 
an access to education) is a rare and desirable good, while growing up in a socially recognized area provides symbolic capital suitable for social advancement, and vice versa. According to Bourdieu, social capital is reproduced in a social network [16,98], which means that it increases and stimulates social stratification. On the other hand, Coleman disseminated the concept of social capital in scientific discourse and neutralized its negative overtones. In his considerations on social capital, Coleman [17] refers to the concept of structure, i.e., a specific map of the paths of social capital flow. According to Coleman, the actors within the structure are equipped with three types of capital: human, physical and social. The levels of these types of capital and their configuration position members of the community in the social world. Next, Putnam [18], in his understanding of social capital proposed the "bright" (positive) approach. In his view, social capital is a network of dependencies and a kind of grease that reduces tensions in a society. Putnam's recognition of social capital legalizes the inclusion of excused private resources (e.g., bonding relationships) in the market game. In line with that approach, Fukuyama [99] understands social capital as an instantiated informal norm which promotes cooperation among individuals and organizations to pursue their own interests.

Putnam makes a distinction between the bridging and bonding social capital (see Table 3). The former is intended to depressurize this capital to stimulate integration and innovation so as to lead to social inclusion (including economic inclusion) and social innovation. The bridging SC facilitates movement in various social networks, e.g., in the labor market. It also allows an access to knowledge and awareness of the possibilities of its use. The bonding SC gives a specific sense of security and social stability so it is of exclusive nature, and thus leads to social exclusion (also economic exclusion) and inhibition of innovation (see Table 3). This division is not sharp; Putnam treats the bonding and bridging social capitals as coexisting analytical categories, which makes it easier to think about social resources. Such thinking about the SC imposes more economically understandable categories, creating a place for knowledge-based economy and reflecting the dynamics of urban change (which is considered as a laboratory in this article) stimulated by the SE.

Table 3. Putnam's social capital division.

\begin{tabular}{lll}
\hline & \multicolumn{1}{c}{ Bridging Social Capital } & \multicolumn{1}{c}{ Bonding Social Capital } \\
\hline Main function & $\begin{array}{l}\text { Connects people of dissimilar } \\
\text { backgrounds and creates larger } \\
\text { networks }\end{array}$ & $\begin{array}{l}\text { Connects people of similar backgrounds } \\
\text { Fosters denser social networks while } \\
\text { bridging social capital that connects } \\
\text { people of dissimilar backgrounds } \\
\text { Creates larger networks }\end{array}$ \\
\hline \multirow{2}{*}{ Main features } & $\begin{array}{l}\text { Supports entrepreneurship, } \\
\text { innovation, } \\
\text { creativity, open attitudes } \\
\text { Breaks existing norms of thinking } \\
\text { and behavior }\end{array}$ & $\begin{array}{l}\text { homogeneous communities } \\
\text { Enhances conformism } \\
\text { Suppresses innovation } \\
\text { Protects individuals in exchange for "not } \\
\text { leaning out of line" }\end{array}$ \\
\hline
\end{tabular}

Source: References [18,36,100,101].

The approaches within the theory of social capital have been criticized for their ambiguity and lack of a developed "universal" measuring apparatus. Various authors synthesized theoretical approaches [102,103]. Against the background of seminal works, the researchers using SCT theory nowadays [102,104-107] refer to Putnam's findings. The division into bridging and bonding social capital is used as a conceptual grid within which social capital is studied in selected aspects $[106,108-110]$.

The criticism of Putnam's concept refers mainly to the lack of a clear division between bridging and bounding dimensions of social capital. Haynes [111] criticizes Putnam's approach for unspecifying the direction of change given as examples of the impact of social capital. This, according to Heynes, 
makes the study conducted through the prism of the SCT tautological, that is explaining the cause of the (social) phenomenon by using its effect. Haynes also states explicitly that social capital cannot be measured by hard indicators. Moreover, social capital refers to both positively and negatively validated social phenomena. This means, as mentioned before, that it has a "dark" side.

The tautological balance [111] between bridging and bonding has created space for reflection on the new components of Putnam's division. Considering this criticism, attempts were made to develop a new type of capital, i.e., linking social capital $[106,107]$. Linking social capital was supposed to fill the liquid space between bridging and bonding and explain the phenomena beyond Putnam's proposal. It seems, however, that to date, no more promising approaches have been developed to cover all of the social capital issues in a way that could replace Putnam's approach.

Despite the discussion raised by Putnam's works, we argue that among all the presented interpretations of social capital, Putnam's approach to social capital is the most useful framework for discussing the sustainability impacts of the SE on the urban community. Three arguments are justifying this belief. First, Putnam's framework considers the growing complexity of the social capital network. Second, it refers to the norms and relationships that can increase the society's efficiency by facilitating coordinated action [36]. Third, Putnam's approach refers to the study of the level of happiness, as the letter phenomenon refers to the quality of life concept when related to life in communities.

The SCT has already been used to explain the potential of social phenomena caused by the SE $[112,113]$. Some work has been also done to describe the role of sharing of resources in the development of modern communities and thus strengthening social capital [105,114-118]. The SCT has also been a basis for understanding micro-processes in the labor market, as the participation in the SE is associated with increased employability [113]. These studies confirm the SCT is predisposed for SE analysis by the fact that it considers the roles of all the actors of the social world, including businesses [119].

Researchers attempt to measure social capital in specific contexts. The SCT "profiling" studies relate to the social consequences caused by the changes in the natural environment [106] and the activities of voluntary organizations [109]. Social capital has also been analyzed in the context of selected values, such as trust in public institutions $[120,121]$ and economic well-being $[110,122]$. These approaches increase SCT's explanatory potential $[106,108,121]$ and measurability of social capital at the expense of a holistic approach to its analysis. However, they seem necessary when it comes to observing the local community.

SCT is also used as a framework for studying relationships in tourist destinations [123-126]. Such an approach refers to the destination by examining it generally at the collective level as a group of social actors and their capacity to act together towards common goals, but this approach remains highly fragmented and vaguely operationalized [103]. However, regarding our attempts to review literature, this approach has been not applied to consider the SE in relationships with social phenomena in local communities in the context of overtourism.

The bonding and bridging social capital sets two extreme equilibrium points in Putnam's approach. Their coexistence in relation to social life, including for business, is a determinant of social consensus. However, the communities face various challenges related to the emergence of SE market practices. The expansion of the SE can be described as a relatively new challenge [127], disrupting this equilibrium, or at least changing the rules for the creation of social capital. For the assumption of Putnam's perspective on the SCT, one can suppose that the SE can strengthen social capital. On the other hand, social capital is one of the guarantees of sustainable development [112].

\section{Sharing Economy and the Sustainability of Urban Destinations: The Social Capital Theory Perspective}

The literature considering the impact of the SE on sustainability of local community in the tourism context summarized in Table 2 tends to characterize the aspects of that impact as positive or negative (or supporting sustainability/unsustainability of local community). Adopting Putnam's 
approach to social capital for the need of an analysis of the sustainability impacts of the SE on a local community in the context of overtourism, it is important to take a collective level approach. Thus, there is a need for a changing of the perspective from individually or commonly experienced changes within neighborhoods to a more general view which excludes interpretations of the impacts in the positive/negative category. Thus, the distinction used in the Table 2 between favoring sustainability and favoring unsustainability impacts must be translated into the SCT conceptual language and transformed into the division between the bridging and bonding social capital. Taking the perspective of the SCT needs a reference to the valence of the impact. As a neutral heuristic construct, social capital cannot be considered as being positive or negative. As the distinction between the bonding and bridging social capitals is not sharp, the coexistence of both is assumed. Thus, an increase in the overall cost of living was considered to be negative as an example, thereby providing an increasingly unsustainabile impact of the SE on a community (Table 2). From the SCT perspective, this outcome should be considered as referring to the bonding social capital, independently from its valency. The outcome of such capital can be related to closing communities and suppressing innovation, which cannot be distinctly considered as being purely negative or positive. In this way, we refer to the SCT in a fashion similar to Rodriguez-Giron and Vanneste [104] who perceives it as "a heuristic tool to study a destination as a group of actors trying to act together, with its positive and negative aspects" (p.5).

The identification of the SE impacts exhibited in Table 2 relates to all the impacts which have been identified in the studies qualified to the selected systematic literature review as an internally undifferentiated group (except sustainability dimension criterium). They are the impacts which are experienced by residents in the consecutive stages of the process of the SE's expansion in the community. For example, disturbance induced by renovations of apartments and evictions can be experienced at the same time as an increase in job opportunities, cultural learning and unfair competition felt by traditional accommodation entrepreneurs. Eventually, a loss of identity and local culture are the final results. Some issues, like the quality of formal regulation and governing towards the SE, can change over time. We are aware of this process as presented by Stergiou and Farmaki [28], but we do not include it in social capital perspective.

The distinction between two dimensions of social capital induces the need to differentiate between the extent of experiencing each one by the members of a community. Social capital is not an individual property and its potential for sustainability does not lie in the hands of single actors. Thus, it has to be considered from the perspective of a local community [17]. For example, the community's sentiment could be different among the tenants playing the role of hosts in a new sharing community.

Classifying the impact of the SE on social capital within a community with a distinction between the bonding and bridging forms of social capital leads to generation of the framework presented in Table 4. In comparison to Table 2, many impacts have been consolidated and reformulated to suit the SCT conceptual framework. The left upper column includes the SE as supporting higher entrepreneurship, innovation, creativity, open attitudes, breaking existing norms of thinking and affecting behavior in communities. That impact might be assessed as both positive and negative, depending on the understanding of the community. The upper right column includes the SE as supporting strong, homogenous communities, tending to provide protection in exchange for 'not leaning out of line'. That impact might be assessed as only being negative for a community, regardless of alternative perceptions.

Nevertheless, many impacts could be categorized in both dimensions of the capital, which is a more significant consequence. Thus, a much wider discussion is needed on how or towards whom the bridging and bonding function of social capital should be interpreted. More authentic interactions between residents and tourists, loss of identity or displacement of low-income or frustrated residents are good ground for this research. Both impacts are induced by the SE expansion. Interactions can be experienced as authentic only by apartment owners being a part of the SE community. Loss of identity in one group could mean a new identity in other groups. Evictions are caused by the SE expansion 
(enhancing bridging capital), but experienced within a traditional community (referring to bonding capital), since social capital is a two-sided coin concept.

Table 4. The impact of the SE on social capital within a community.

\begin{tabular}{ll}
\hline Referring to bridging social capital & Referring to bonding social capital \\
\hline $\begin{array}{l}\text { A stronger and more diverse local economy and } \\
\text { culture }\end{array}$ & \\
$\begin{array}{l}\text { Extended use of local offers and infrastructure } \\
\text { Greater liveability }\end{array}$ & $\begin{array}{l}\text { Increase in the overall cost of living } \\
\text { Decrease in affordable housing }\end{array}$ \\
Increasing employment and entrepreneurship & Shrinking local community in the area \\
A more innovative community; emergence of & Depopulation of buildings \\
SE-related services & Decrease in sense of safety \\
Empowering of women in community & Decline in community well-being \\
Increase in value of the local real-estate market & Impairment of community health \\
Fostering community pride & Social unrest \\
Increase in tourism spending and municipal revenues & Loss of the sense of community \\
Raise of gray accommodation market and tax evasion & Loss of identity and local culture \\
Ungoverned informal economy & Social segregation in residential areas \\
Emerging of loopholes in the law and regulations & Colonization of the lived spaces of urban housing \\
Unfair competition in the local market & 'Drag effect' in local estate market related to spatial \\
Decrease in revenues for traditional accommodation & concentration of short-term rentals \\
businesses & The influx of low-cost tourists with limited spending \\
Commodification of private and public assets and & power \\
space & \\
Increasing cultural exchange and cultural learning & \\
\hline
\end{tabular}

Referring to the sharing platform-modified social capital
Higher incomes for owners renting their properties
Improvements in residential unitsNew socio-spatial relations restricting residents and traditional stakeholders
Social segregation in residential areas
Increasing sense of authentic interactions
Racial disadvantages
New identity and local culture
Increasing cultural exchange and cultural learning
Fostering of local entrepreneurship and small businesses
Colonization of the lived spaces of urban housing
Greater destination loyalty of tourists
Erosion of workers' rights
Decline in community well-being referring to reputational system of sharing economy platforms
Moral issues related to impacts on tourists
Increase in precarious jobs and casualization of labor with no social security coverage
External control of local housing/tourist market by the SE platform owners
Money transferred by sharing platforms outside local economic systems

Source: own elaboration; based on Table 2 .

The majority of the SE impacts which were classified as favoring sustainability refers to the bridging side of social capital. However, the inclusive capital is connected with the impacts acknowledged as being disruptive. They are all of economic origin and are related to a new form of business relationships which have been triggered by the SE. The new rules of competition, under regulated areas of social activity and commodification of space are major examples of this disruption. On the other hand, the bonding function of the social capital comprises only the SE impacts, which were acknowledged to favor reduced sustainability. The majority of them are in the social and environmental domain.

The division between the bridging and bonding social capital also evokes impacts assigned to the SE community only, but have a typical bonding characteristic within the new community, thereby sharing a platform-modified area of social capital within local communities affected by overtourism. Higher incomes and social segregation in residential areas on the one hand, and racial disadvantages and external control of local housing market by the SE platform owners on the other hand are good 
examples of this. The former examples strengthen exclusiveness externally, while the latter are experienced only within the members of this group, which strengthens the group's internal consistency. In this setting, the bonding social capital becomes more inclusive as hosts are colonizing the common lived spaces of housing buildings and commodifying it as the resources used in sharing business. Moreover, the bridging capital becomes more exclusive, which means that it requires participation in sharing economy platforms as well as knowledge and ability to participate in business in accordance with the SE's community rules.

In this realm, the SE platforms become the moderators of the emerged sharing platforms-modified social capital (see the lower part of Table 4). This new configuration of social capital can occur due to the factors stimulated by the SE. Some indicators of this configuration of social capital can be distinguished as:

- informational driven (ICT-platform-based/driven)—driven by strictly-regulated platform principles and rules; the local norms are excluded or indirectly involved-which is disruptive towards local norms, regulations and culture;

- driven by a global, spatial-free community based on technological environment impacting local socio-spatial environments;

- micro-focused (the accommodation item, i.e., room or apartment is a basic element of sharing and competition, not the accommodation facility);

- $\quad$ non-hierarchical, but centrally-regulated by the platform owner;

- creating the sense of community within platform users as a driver of social activities and their outcomes;

- shared expectations and attitudes towards the local community are framed by information provided by and on sharing platform;

- driven by trust towards sharing a platform's users and platform control mechanism; relationships based on digitalized interactions;

- reciprocity confined within a sharing platform community alongside a limited engagement in community building.

Some characteristics of more general nature specific to this configuration of social capital can also be distinguished, such as: an orientation towards the future; heterogeneity (diversity); enhanced susceptibility to a fast and frequent transformation (and an ability to a complete transmutation at times); choice selectivity of city development goals and spheres as far as interests are concerned; a tendency towards a strong teleological, i.e., purposeful, orientation of social participation (undertook activities); or a powerfully stimulating influence on the development of the so-called citizen journalism. A similar proposition to extend Putnam's concept of bonding and bridging social capital when analyzing tourist destination can also be found in the work of Rodriguez-Giron and Vanneste [103]. They suggest introducing a linking social capital which points to vertical social ties among actors who control key resources. Interpreting this concept in the shadow of the SE, this capital refers mainly to sharing platforms, which links it to our concept of sharing platforms-modified social capital.

As the concept of sharing platforms-modified social capital is of a viewpoint character, its empirical identification could be challenging while considering both the difficulties occurring in the attempts of verification of social capital concepts and the difficulties associated with the tourism research obtained from an interdisciplinary and multifaceted analysis of this phenomenon. One of the most relevant problems could certainly be the fact that the identification and analysis of the relations taking place among the examined phenomena, i.e., the SE, sustainability, social capital and overtourism, is often challenging and that this identification and analysis could be possible only in the medium-term or even the long-term. For that reason, the matrix exhibited in Figure 1 could be a useful tool for such analyses. 


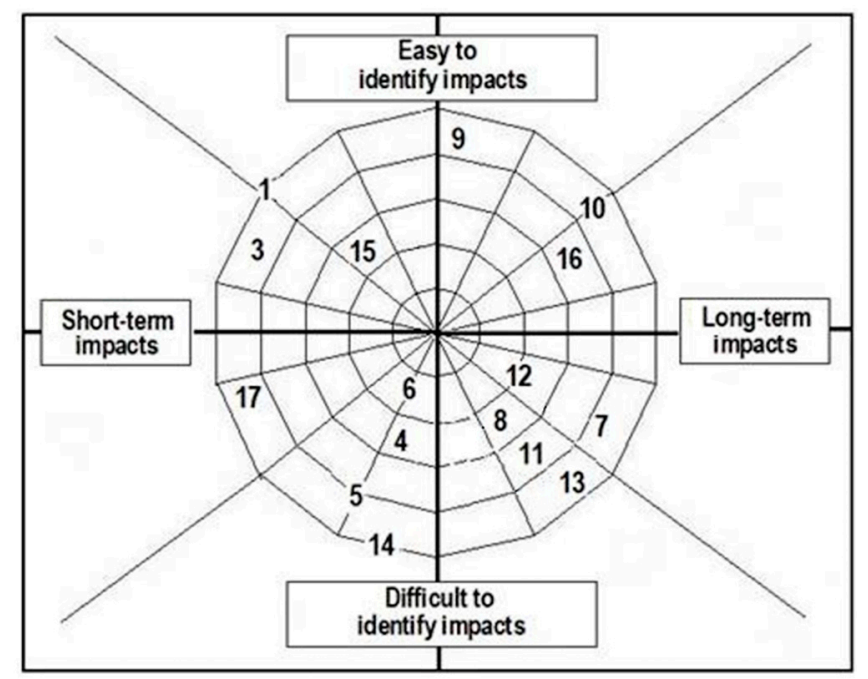

Figure 1. Matrix for identifying and analyzing the impact of the SE on social capital of urban destinations. Legend: 1 Higher incomes of owners renting their properties; 2 Improvements in residential units; 3 New socio-spatial relations restricting residents and traditional stakeholders; 4 Social segregation in residential areas; 5 Increasing sense of authentic interactions; 6 Racial disadvantages; 7 New identity and local culture; 8 Increasing cultural exchange and cultural learning; 9 Fostering of local entrepreneurship and small businesses; 10 Colonization of the lived spaces of urban housing; 11 Greater destination loyalty of tourists; 12 Erosion of workers' rights; 13 Decline in community well-being referring to reputational system of sharing economy platforms; 14 Moral issues related to impacts on tourists; 15 Increase in precarious jobs and casualization of labor with no social security coverage; 16 External control of local housing/tourist market by the SE platform owners; 17 Money transferred by sharing platforms outside local economic system.

Figure 1 exhibits all the most relevant manifestations of the sharing economy impact identified and shown in Table 4 as a new configuration of social capital. For example, higher incomes earned by the hosts (impact 1) could be identified almost immediately and without using complex research tools, while a decline in community well-being (impact 13) and formation of a new identity and local culture (impact 7) could be a complex and long-term challenge. Moreover, although transferring a portion of revenues generated by short-term rentals outside the local economic system (impact 17) occurs during the time of booking by users, its size can be difficult to estimate. On the other hand, studying the impact of colonization of the lived spaces of urban housing by the SE (impact 10) could be possible only in the long-term. Thus, the use of the matrix allows us to include the complexity of the analyzed phenomena and to refer to them in a relatively uncomplicated way, with no necessity to evaluate them (according to the culturalist perspective). Moreover, it facilitates the choice of appropriate methods, techniques and research procedures including, depending on a scale of possibilities of scientific recognition and probable time of occurrence, virtually all the potential sharing economy impacts on social capital and the sustainable development of cities in the context of overtourism.

\section{Conclusions}

As a relatively young and controversial phenomenon, principally caused by the recent digital transformation, the SE generates new factors which influence the sustainable development of local communities [128]. In this viewpoint article, we have considered the impact of the sharing economy on sustainability from the perspective of urban communities. We have presented overtourism as resulting from, collating or contributing to the sharing economy. We have also reflected upon the discussion, present in the literature, on a positive and negative impact of the SE on the environmental, economic and social aspects of the urban community in the tourism context. The picture that results from this discussion is fragmented and vague, so the need to find a new theoretical viewpoint has been pointed 
out. Therefore, this article suggests that SCT is the framework allowing new insight into discussion on the impact of the SE on urban communities. It transfers the evaluative character of discussion to more general dimensions of bonding and bridging character of dynamically changing conditions of actions within communities. This article leads to conclusions on the bonds between SE, social platforms and sustainability of urban communities, which we present as a conceptual model. Then, we move to the conclusions on the key relationships assumed by this model. They refer to the influence of SE on social capital and the influence of social capital on sustainability in the context of overtourism in urban communities. In this way, the article refers to Dredge and Gyimothy's [19] call to show the broader impacts of the SE on local and regional economies and communities.

By an introduction of the SCT approach, this article implies an initial framework that extends understanding of the impact of the SE on sustainability. Thus, it presents a more colourful but also more organized picture of the changes that take place at the junction of new ways of doing business imposed by sharing platforms and local communities affected by the emergence of these activities. The designation of bridging and bonding social capital shows the way the SE influences a local community. In the traditional concept of the social capital, the community-regardless of whether it is a district community or a neighborhood one-emanates bonding capital within which all the residents know or are familiar with each other. The SE community members-the so-called peers, i.e., hosts and guests-produce and transmit bridging social capital through a short-term rental disseminated by the SE platforms. Both greater liveability of the neighborhoods and unfair competition in the local market are the impacts referring to inclusive social capital. The same phenomenon is associated with consumers (potential peers, i.e., hosts and guests) who do not use existing solutions but have the awareness and tools necessary for applying them. Adopting the social capital theory to study the impact of the sharing economy on local communities in the overtourism context allowed us to construct a conceptual model which illustrates the relations among the most crucial elements in the complex process of the SE impact on the sustainable development of communities in city destinations affected by overtourism (see Figure 2).

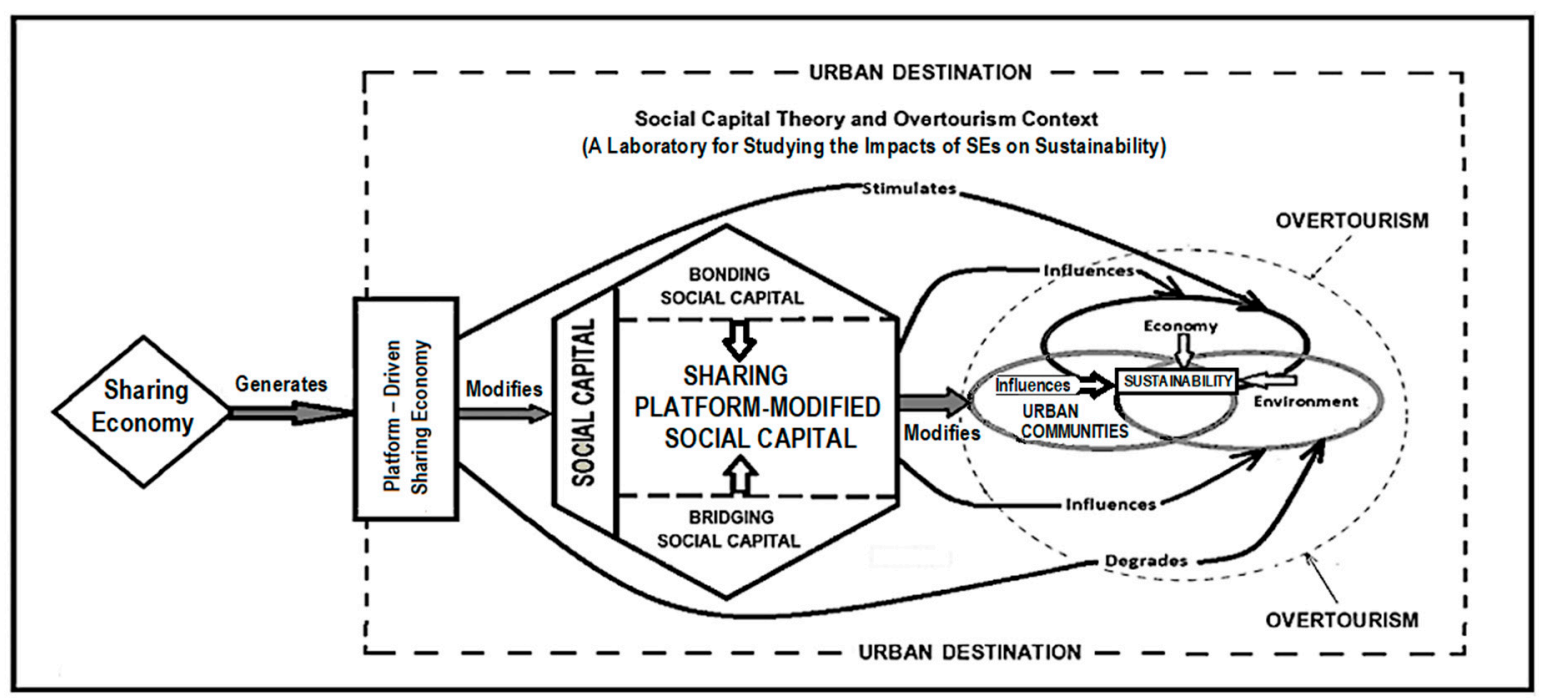

Figure 2. A model for studying the impact of the SE on the sustainability of urban destinations affected by overtourism. Source: Own elaboration.

The model presents the SE as an initiating factor-generated and distributed through sharing platforms focusing in the accommodation sector-which influence urban destinations by modifying social capital. Additionally, the SE directly influences the other dimension of a destination's development by stimulating the economy and degrading the environment, as is exhibited on Table 2 . Nevertheless, the model focuses on changes in the social sphere within local communities and 
sustainability in urban destination experiencing overtourism. Overtourism is the context, not the main subject of our analysis. Social capital is the central element of the model. Being under the influence of the SE, it undergoes significant modifications and also causes changes in the last element of the model (right side of Figure 2), i.e., sustainable development of the destination. The modifications apply to bonding and bridging categories of social capital, sharpening their most significant features, discussed in Table 4 and Figure 1. Thus, a new configuration of social capital emerges, i.e., sharing platform-modified social capital. It reveals some features partly taken over from both function of social capital identified by Putnam; however, the configuration is profoundly transformative. The process of changes in social capital is identified by the arrows and the dashed lines indicating the direction of flow and the scope of the process of shaping a new configuration of social capital. Over time, this capital may become dominant, modifying the entire system of sustainable urban development. Its impact does not only concern the community, but also other components of sustainable development, i.e., the economy and the environment.

The gradual transformation of the elements of the bonding-type capital into the bridging-type capital is associated with the expanding network of social relations due to the development of sharing economy. Conversely, the transformation of some aspects of the bridging-type capital into the bonding-type capital occurs mostly due to adverse changes in the city residents' quality of living incurred by the sharing economy. These processes result in the growing number of the reconfigured elements, while the most significant impact force lies in the bridging function of social capital. However, this force is not strong enough in the confrontation with the bonding-type capital to ultimately transmute one form of capital into the other. This leads to a situation where the new elements appear and come to gain significance.

The SCT view which we introduce to the discussion on the SE impact on local communities leads to certain conclusions in the field of sustainability. We assume that both bonding and bridging social capital—as coexisting in social life—are favorable for the sustainability of local communities, as they are in constant pursuit of mutual balance. For urban communities, all of the forms of social capital are required to support collective actions that might transfer to perceived short-term sustainability as well as to unsustainability. In the long-term view to which sustainable development finally refers, this 'game of balance' between two types of social capital should be perceived as an representation of sustainability. Tourism is associated with the influx of tourists, so the development of the SE enriches the social capital of the destination with the elements characteristic of the bridging social capital. The social capital enrichment is deep, especially in the spheres of the development of the community, entrepreneurship and openness to the world as well as the resulting advantages (economic, social, cultural, referring to the social modernization, etc.). At the same time, the bonding capital grows in the communities affected by overtourism under the influence of the sharing economy. Its growth manifests itself in undertaking various actions which integrate local communities by generating (or enhancing) activities to protect their interests and the quality of living that is endangered due to the SE's effects. Thus, we can conclude that in both cases, we deal with the accumulation of the social capital induced by the sharing economy in the context of overtourism.

The link between the sharing platform-modified social capital and urban communities in the context of overtourism is multidirectional. On the one hand, the SE itself affects the residents' quality of living and the environment negatively, as it changes the equilibrium between the bridging and bonding capital. The new configuration of social capital might favor unsustainability, as it is not balanced by any of these two traditional types of capital. It manifests itself in a reputation system imposed by the sharing economy platform to trigger and strengthen new binary host-guest relation, at the same time 'bracketing out' other tenants and creating new disruptive geographies [33]. In this sense, an 'exclusive face' of this new social capital affects the traditional bonding capital (as shown in Table 4). However, the relationship between them does not refer to balance but rather to confrontation. This explains the negative resident perceptions and attitudes towards the SE and the unsustainability discussion of this phenomenon. 
On the other hand, the sharing platform-modified social capital helps to establish the network and continuously growing social relations resulting from a growing influx of tourists and the activity of the institutions engaged in providing them with various services. Also, it brings about changes in social capital, re-uniting local communities around the protests against the negative changes it causes to their standard of living. In effect, alongside its negative impact on environment, we have to deal with the advantageous changes in two other spheres which make up sustainable development, which are society and the economy. Thus, the sharing platform-modified social capital refers not only to a certain (and moderately fixed) set of characteristics of the traditionally perceived social capital but also to the level of its saturation. It can manifest itself in openness to new ideas, higher networking of social and economic structures, an increase in entrepreneurship and a readiness to develop new business models. The new balance, and thus new exclusivity, changes the conditions of the market game. It allows and involves actors who do not exist as part of traditionally understood exclusivity. This phenomenon can be compared to a sea wave, which in a diffuse, but a successive way models the shape of the coast regardless of the assumptions of its hosts. Virtual platforms are here a new kind of a market player which, although physically inaccessible in space (like a hotel reception), sets the rules of a market game that not all the current players are aware of. In effect, we deal with the modification of the configuration of the basic elements which make up the categories of the generally conceived social capital and also - in many cases—with its new elements.

Regarding the Putnam approach to bonding social capital as important for survival and bridging social capital as being good for making progress [129], we can state that sharing platform-modified social capital is particularly crucial to 'make progress' in this very relevant branch of the sustainable development of tourist cities. At the same time, however, that capital is explicitly negative for destinations, at least concerning social and environmental sustainability. In the case of the economic aspect, the issue is more complex, yet the opinions of a negative impact can also prevail (as exhibited in Table 2), particularly in the long-term. As social capital cannot be considered selectively, concerning one community or spatial area, the impact of the SE should not be considered in these terms either. Thus, even if the SE leads to some local unsustainability, e.g., in the form of overtourism, it cannot be generalized because in a broader business landscape, sustainability may increase at the same time. However, the evaluation of this impact should include whether the social capital is treated in an autotelic or instrumental way at a given moment [130], as well as which of these two functions is regarded to be the dominating one. This is strongly emphasized by Coleman [17] in his functionalist approach and integral vision of the social realm. Schindler [130] adds that for a given situation, one can decide which function the social realm has and which elements of a social structure appear relevant, whether they serve or do harm, or whether they are neutral for a community. The article is in line with another of Schindler's opinions that it is not the amount of social capital that counts, but its specific local features and the way it is used: to what extent it serves the communities which generate it and to what extent it is instrumentalized even contrary to their interests [130]. Thus, a question appears: to what extent can entities use social capital from a local community in a way which is not necessarily compatible with a community's interests?

Summing up, this article contributes to the discussion on sustainability of SE by adopting the SCT framework to explain its role and extent of impact on local communities in relation to overtourism syndrome. As the tourism industry is one of several spheres where the SE is diffusing, the study's results can be helpful for understanding the way that SE influences social capital and contributes to sustainability within urban communities. Following this approach, this article contributes to the discussion on overtourism by focusing on the relations between the SE and local communities, instead of only identifying the effects of the SE. Thus, it provides the new conceptual framework for studying the implications resulting from overtourism, which is in line of suggestions of Koens et al.'s [26] and Dodds and Butler's [74] calls for more in-depth insight into both SE sustainability and overtourism. Moreover, it supports Rodriguez-Giron and Vanneste's [103] suggestions that SCT may be helpful 
in understanding the gap between intentions and efforts, as well as what can contribute to the improvement of a destination's ability to handle the impact of SE in more sustainable ways.

This article also contributes to discussion on social tensions that manifest themselves in the phenomenon of overtourism. The 'sharing effect' takes place in the sphere of accommodation host-neighbor relationships, i.e., business activities of flats/homes owners, the consequences of these activities for other tenants and their mutual inter-reactions. The tourist effect refers to the fact the accommodation is rented by tourists who are culturally-distant and use them for a short term and for leisure purposes, and therefore it is based on the interactions among them and other members of the neighborhood. Thus, medium-term problems arise (the long-term issues could not be observed yet) which affect local communities in many ways [26,27,74,92]. Applying Putnam's approach to the SCT, we can explain the role of the SE in the rise and growth of overtourism in urban communities as a gate through which the new configuration of social capital flows and emerges in a traditional community, enhancing the bridging side of social capital but confronting its bonding side. Overtourism, as a negatively assessed and perceived but short-term phenomenon, is fueled by the new configuration of social capital introduced by the SE in local communities. The dynamics of the violent growth of the SE in urban communities highlights the unsustainable sharing platform-driven social capital and pushes its inclusiveness to the background, causing the calls for laws and regulations $[21,32,39,51]$.

The picture of the relations among analyzed phenomena and their effects is largely simplified, as the research in this field is still rare and underdeveloped. Similarly, our considerations have limitations resulting from the fact that they were based on a literature review and the area of the SE limited to the accommodation sector, although it certainly affects the overtourism to the most significant extent. Additionally, only the English-language studies indexed in the Web of Science and Scopus databases were selected for the systematic analysis. It can be expected that the research conducted in other countries and published in other languages could enrich the material and thus affect the cognitive and explanatory values of this work in a positive way.

This study puts forward several suggestions for further studies. To name a few, we start with sharpening of the discussion about what contemporary bridging and bonding SC becomes under the influence of $\mathrm{SE}$ in the area of tourism. Identification of the interplay between bridging, bonding and the new configuration of social capital affected by SE is sets the next issue that awaits identification. Having this in mind, we recommend further studies on the mechanisms and effects of the sharing economy and overtourism on the sustainable development of destinations and their communities using the concept of sharing platform-modified social capital and the matrix for identifying and analyzing the impact of the SE on the social capital of urban destinations. Understanding the factors that moderate generation of new configurations of social capital could be beneficial for academic and practical discussion. Finally, in the context of overtourism, studies could focus on finding ways of improving a destination's social capital-related capacity to self-determine its development path when it is affected by SE. As this article is strictly of a theoretical nature-which is its main limitation-the arguments and conclusions should be verified empirically by studying the impact of the SE on a selected community affected by overtourism. Analysis of the impact of the SE on the sustainability of a urban community using Putnam's approach of SCT in other sectors of the tourism industry and other spheres of social activity is also suggested.

Author Contributions: This article is a joint work of the four authors. Conceptualization, P.Z. and A.W.; literature review, P.Z., A.W. and W.A.; writing-original draft preparation, P.Z., G.L., A.W. and W.A.; writing-review and editing, P.Z. and G.L.; visualization, P.Z. and W.A.; supervision, P.Z. and G.L. All authors have read and agreed to the published version of the manuscript."

Funding: This research has been supported by a Poznan University of Economics and Business internal grant program called PUEB for Science-Novel directions in the field of economics". Project title: "Evolution of inter-organisational relationships as the result of the sharing economy's development: micro, meso and macroeconomic implications." 
Conflicts of Interest: The authors declare no conflict of interest. The funders had no role in the design of the study; in the collection, analyses, or interpretation of data; in the writing of the manuscript, or in the decision to publish the results.

\section{Appendix A}

Table A1. Theoretical/Conceptual frameworks utilized in studies on the sharing economy in (over)tourism context.

\begin{tabular}{|c|c|c|c|c|}
\hline Study & Main Purpose & Main Focus * & Theoretical Framework & Methods \\
\hline $\begin{array}{l}\text { Martín, Martínez, } \\
\text { and Fernández, } \\
2018[3]\end{array}$ & $\begin{array}{c}\text { Measures residents' attitudes } \\
\text { towards tourism and its } \\
\text { impact }\end{array}$ & OT & Social Exchange Theory & $\begin{array}{l}\text { Empirical research; qualitative } \\
\text { and quantitative approach; } \\
\text { semi-structured face to face } \\
\text { interviews; telephone survey; } \\
\text { Barcelona case study }\end{array}$ \\
\hline $\begin{array}{c}\text { Mody, Suess, and } \\
\text { Dogru, } 2019 \text { [38] }\end{array}$ & $\begin{array}{l}\text { Examines the residents' } \\
\text { attitude (perception and } \\
\text { support/lack of support) } \\
\text { towards Airbnb }\end{array}$ & SE & Social Exchange Theory & $\begin{array}{c}\text { Empirical research; } \\
\text { quantitative study; An online } \\
\text { survey among USA residents }\end{array}$ \\
\hline $\begin{array}{l}\text { Gutiérrez-Taño, } \\
\text { Garau-Vadell, and } \\
\text { Díaz-Armas, } \\
2019 \text { [2] }\end{array}$ & $\begin{array}{l}\text { Examines residents' } \\
\text { perception of the impacts of } \\
\text { the P2P accommodation and } \\
\text { their attitudes towards it and } \\
\text { support }\end{array}$ & SE & Social Exchange Theory & $\begin{array}{c}\text { Empirical research; } \\
\text { Quantitative study; } \\
\text { questionnaire survey; Majorca } \\
\text { case study }\end{array}$ \\
\hline $\begin{array}{c}\text { Stergiou and } \\
\text { Farmaki, 2019 [28] }\end{array}$ & $\begin{array}{l}\text { Examines resident perceptions } \\
\text { regarding the impact of P2P } \\
\text { accommodation growth, and } \\
\text { specifically Airbnb, on their } \\
\text { neighborhoods }\end{array}$ & SE & Social Exchange Theory & $\begin{array}{c}\text { Empirical research; } \\
\text { Qualitative approach; } \\
\text { semi-structured in-depth } \\
\text { interviews; Athens case study }\end{array}$ \\
\hline $\begin{array}{l}\text { Martín-Martín, } \\
\text { Ostos-Rey, and } \\
\text { Salinas-Fernández, } \\
\text { 2019 [32] }\end{array}$ & $\begin{array}{l}\text { Analyzes the positive and } \\
\text { negative aspects of } \\
\text { unregulated new markets in } \\
\text { order to pinpoint a solution to } \\
\text { the problems that those } \\
\text { markets have to face }\end{array}$ & SE & $\begin{array}{l}\text { Social Exchange Theory; } \\
\text { Neoclassical economics }\end{array}$ & $\begin{array}{l}\text { Theoretical approach; desk } \\
\text { research }\end{array}$ \\
\hline $\begin{array}{c}\text { der Heidt, } \\
\text { Muschter, } \\
\text { Caldicott, and Che, } \\
2019 \text { [31] }\end{array}$ & $\begin{array}{l}\text { Explores the perception of key } \\
\text { informants on the impacts of } \\
\text { Airbnb on the local } \\
\text { community, as well as possible } \\
\text { solutions to the problems }\end{array}$ & SE & $\begin{array}{c}\text { Social Representation } \\
\text { Theory }\end{array}$ & $\begin{array}{c}\text { Empirical reseach; Qualitative } \\
\text { approach; semi-structured } \\
\text { in-depth interviews; Byron } \\
\text { (Australia) case study }\end{array}$ \\
\hline $\begin{array}{l}\text { Valdivielso and } \\
\text { Moranta, 2019 [42] }\end{array}$ & $\begin{array}{l}\text { Analyzes the debate around } \\
\text { tourism edgrowth in Balearic } \\
\text { Islands }\end{array}$ & OT & $\begin{array}{l}\text { Tourism degrowth } \\
\text { concepts }\end{array}$ & $\begin{array}{l}\text { Desk research; critical } \\
\text { discourse analysis }\end{array}$ \\
\hline $\begin{array}{c}\text { Namberger, } \\
\text { Jackisch, Schmude, } \\
\text { and Karl, 2019 [4] }\end{array}$ & $\begin{array}{l}\text { Investigates residents' } \\
\text { perceptions, their feelings and } \\
\text { reactions to tourism } \\
\text { development }\end{array}$ & OT & $\begin{array}{l}\text { Social carrying capacity } \\
\text { concept }\end{array}$ & $\begin{array}{c}\text { Empirical research; } \\
\text { quantitative study; a self- } \\
\text { administered, door-to-door } \\
\text { household survey; Munich } \\
\text { case study }\end{array}$ \\
\hline $\begin{array}{l}\text { Pinke-Sziva, Smith, } \\
\text { Sziva, and Olt, and } \\
\text { Berezvai } 2019 \text { [30] }\end{array}$ & $\begin{array}{l}\text { Analyzes the phenomenon of } \\
\text { overtourism with specific } \\
\text { reference to the night-time } \\
\text { economy }\end{array}$ & OT & Own framework design & $\begin{array}{c}\text { Mapping, observation, } \\
\text { interviews and questionnaires } \\
\text { with local residents, visitors } \\
\text { and tourists; Budapest case } \\
\text { study }\end{array}$ \\
\hline $\begin{array}{l}\text { Gössling and Hall, } \\
2019 \text { [20] }\end{array}$ & $\begin{array}{l}\text { Conceptualizes the sharing } \\
\text { economy in accommodation } \\
\text { sector in comparison to the } \\
\text { wider collaborative economy, } \\
\text { and discusses its social, } \\
\text { economic, environmental, and } \\
\text { political impacts in } \\
\text { comparison to the sustainable } \\
\text { development goals }\end{array}$ & SE & $\begin{array}{l}\text { United Nations' } \\
\text { Sustainable Development } \\
\text { Goals framework }\end{array}$ & $\begin{array}{l}\text { Desk research; literature } \\
\text { review; discourse analysis }\end{array}$ \\
\hline $\begin{array}{l}\text { Postma and } \\
\text { Schmuecker, } \\
2017[45]\end{array}$ & $\begin{array}{l}\text { Assesses causes of fields of } \\
\text { conflicts between residents } \\
\text { and tourists and their impact }\end{array}$ & UT & Own framework design & $\begin{array}{c}\text { Desk research; Hamburg case } \\
\text { study }\end{array}$ \\
\hline $\begin{array}{l}\text { Garcia-Ayllon, } \\
2018 \text { [25] }\end{array}$ & $\begin{array}{c}\text { Analyzes urban } \\
\text { transformation associated } \\
\text { with Airbnb growth }\end{array}$ & SE & Own framework design & $\begin{array}{l}\text { GIS spatiotemporal indicators } \\
\text { Madrid, Barcelona, and Palma } \\
\text { de Mallorca case studies }\end{array}$ \\
\hline
\end{tabular}


Table A1. Cont.

\begin{tabular}{|c|c|c|c|c|}
\hline Study & Main Purpose & Main Focus * & Theoretical Framework & Methods \\
\hline $\begin{array}{l}\text { Stabrowski, } \\
2017 \text { [33] }\end{array}$ & $\begin{array}{l}\text { Examines the material and } \\
\text { discursive practices through } \\
\text { which Airbnb has produced } \\
\text { new social relations of } \\
\text { domestic property }\end{array}$ & SE & $\begin{array}{l}\text { Production of space } \\
\text { concept; performativity in } \\
\text { economics concept }\end{array}$ & $\begin{array}{l}\text { Desk research; critical } \\
\text { examination of the discourses } \\
\text { and practices of Airbnb in the } \\
\text { popular media, courts of law } \\
\text { and public hearings; New } \\
\text { York case study }\end{array}$ \\
\hline $\begin{array}{l}\text { Szromek, Kruczek, } \\
\text { and Walas, } \\
2020[97]\end{array}$ & $\begin{array}{l}\text { Measures residents' attitudes } \\
\text { towards tourism development }\end{array}$ & OT & $\begin{array}{l}\text { Irridex model; Tourism } \\
\text { Area Life Cycle }\end{array}$ & $\begin{array}{l}\text { Quantitative approach; } \\
\text { questionnaire survey }\end{array}$ \\
\hline Cheng, 2016 [1] & $\begin{array}{c}\text { Provides an objective, } \\
\text { systematic and holistic review } \\
\text { of the SE literature to uncover } \\
\text { the theoretical foundations } \\
\text { and key themes underlying } \\
\text { the field }\end{array}$ & SE & Not applicable & $\begin{array}{c}\text { Systematic literature review } \\
\text { using co-citation analysis and } \\
\text { content analysis }\end{array}$ \\
\hline $\begin{array}{l}\text { Agyeiwaah, } \\
2019 \text { [24] }\end{array}$ & $\begin{array}{l}\text { Theoretically explores the } \\
\text { nexus between over-tourism } \\
\text { and sustainable consumption } \\
\text { in cities, highlighting } \\
\text { governments' inevitable role } \\
\text { in this successful convergence }\end{array}$ & OT & Not applicable & $\begin{array}{c}\text { Selective systematic literature } \\
\text { review; Macau (China) case } \\
\text { study }\end{array}$ \\
\hline
\end{tabular}

* OT—overtourism, SE—sharing economy, UT—urban tourism.

\section{References}

1. Cheng, M. Sharing economy: A review and agenda for future research. Int. J. Hosp. Manag. 2016, 57, 60-70. [CrossRef]

2. Gutiérrez-Taño, D.; Garau-Vadell, J.B.; Díaz-Armas, R.J. The influence of knowledge on residents' perceptions of the impacts of overtourism in P2P accommodation rental. Sustainability 2019, 11, 1043. [CrossRef]

3. Martín Martín, J.M.; Guaita Martínez, J.M.; Salinas Fernández, J.A. An analysis of the factors behind the citizen's attitude of rejection towards tourism in a context of overtourism and economic dependence on this activity. Sustainability 2018, 10, 2851. [CrossRef]

4. Namberger, P.; Jackisch, S.; Schmude, J.; Karl, M. Overcrowding, Overtourism and Local Level Disturbance: How Much Can Munich Handle? Tour. Plan. Dev. 2019, 16, 452-472. [CrossRef]

5. Dredge, D.; Gyimóthy, S.; Birkbak, A.; Jensen, T.E.; Madsen, A.K. The Impact of Regulatory Approaches Targeting Collaborative Economy in the Tourism Accommodation Sector: Barcelona, Berlin, Amsterdam and Paris; Aalborg University: Aalborg, Denmark, 2016.

6. Jordan, P.; Pastras, P.; Psarros, M. Managing Tourism Growth in Europe; The ECM: Dijon, France, 2018.

7. UNWTO. 'Overtourism'?-Understanding and Managing Urban Tourism Growth beyond Perceptions, Executive Summary; UNWTO: Madrid, Spain, 2018.

8. Bakker, M.; Twining-Ward, L. Tourism and the Sharing Economy: Policy and Potential of Sustainable Peer-to-Peer Accommodation; World Bank: Washington, DC, USA, 2018.

9. Peeters, P.; Gössling, S.; Klijs, J.; Milano, C.; Novelli, M.; Dijkmans, C.; Eijgelaar, E.; Hartman, S.; Heslinga, J.; Isaac, R.; et al. Research for TRAN Committee-Overtourism: Impact and Possible Policy Responses; European Parliament, Policy Department for Structural and Cohesion Policies: Brussels, Belgium, 2018.

10. McKinsey \& Company. WTTC Coping with Success: Managing Overcrowding in Tourism Destinations; McKinsey \& Company: New York, NY, USA, 2017.

11. Battino, S.; Lampreu, S. The role of the sharing economy for a sustainable and innovative development of rural areas: A case study in Sardinia (Italy). Sustainability 2019, 11, 3004. [CrossRef]

12. Daunorienè, A.; Drakšaitè, A.; Snieška, V.; Valodkienè, G. Evaluating Sustainability of Sharing Economy Business Models. Procedia Soc. Behav. Sci. 2015, 213, 836-841. [CrossRef]

13. Geissinger, A.; Laurell, C.; Öberg, C.; Sandström, C. How sustainable is the sharing economy? On the sustainability connotations of sharing economy platforms. J. Clean. Prod. 2019, 206, 419-429. [CrossRef]

14. Kathan, W.; Matzler, K.; Veider, V. The sharing economy: Your business model's friend or foe? Bus. Horiz. 2016, 59, 663-672. [CrossRef] 
15. Martin, C.J. The sharing economy: A pathway to sustainability or a nightmarish form of neoliberal capitalism? Ecol. Econ. 2016, 121, 149-159. [CrossRef]

16. Bourdieu, P. The forms of capital. In Handbook of Theory and Research for the Sociology of Education; Richardson, J., Ed.; Greenwood: New York, NY, USA, 1986; pp. 241-258.

17. Coleman, J. Social Capital in the Creation of Human Capital. Am. J. Sociol. 1988, 94, S95-S120. [CrossRef]

18. Putnam, R.D.; Leonardi, R.; Nanetti, R.Y. Making Democracy Work: Civic Traditions in Modern Italy; Princeton University Press: Princeton, NJ, USA, 1994.

19. Dredge, D.; Gyimóthy, S. The collaborative economy and tourism: Critical perspectives, questionable claims and silenced voices. Tour. Recreat. Res. 2015, 40, 286-302.

20. Gössling, S.; Michael Hall, C. Sharing versus collaborative economy: How to align ICT developments and the SDGs in tourism? J. Sustain. Tour. 2019, 27, 74-96. [CrossRef]

21. Furukawa, N.; Onuki, M. The design and effects of short-term rental regulation. Curr. Issues Tour. 2019. [CrossRef]

22. Koh, E.; King, B. Accommodating the sharing revolution: A qualitative evaluation of the impact of Airbnb on Singapore's budget hotels. Tour. Recreat. Res. 2017, 42, 409-421. [CrossRef]

23. Mhlanga, O. Peer-to-peer-travel: Is Airbnb a friend or foe to hotels? Int. J. Cult. Tour. Hosp. Res. 2019, 13, 443-457. [CrossRef]

24. Agyeiwaah, E. Over-tourism and sustainable consumption of resources through sharing: The role of government. Int. J. Tour. Cities 2019, 6, 99-116. [CrossRef]

25. Garcia-Ayllon, S. Urban transformations as an indicator of unsustainability in the P2P mass tourism phenomenon: The Airbnb Case in Spain through three case studies. Sustainability 2018, 10, 2933. [CrossRef]

26. Koens, K.; Postma, A.; Papp, B. Is overtourism overused? Understanding the impact of tourism in a city context. Sustainability 2018, 10, 4384. [CrossRef]

27. Novy, J. Urban tourism as a bone of contention: Four explanatory hypotheses and a caveat. Int. J. Tour. Cities 2019, 5, 63-74. [CrossRef]

28. Stergiou, D.P.; Farmaki, A. Resident perceptions of the impacts of P2P accommodation: Implications for neighbourhoods. Int. J. Hosp. Manag. 2019. [CrossRef]

29. Rickly, J.M. Overtourism and authenticity. In Overtourism: Issues, Realities and Solutions; Dodds, R., Butler, R.W., Eds.; De Gruyter: Berlin, Germany, 2019; pp. 46-61.

30. Pinke-Sziva, I.; Smith, M.; Olt, G.; Berezvai, Z. Overtourism and the night-time economy: A case study of Budapest. Int. J. Tour. Cities 2019, 5, 1-16. [CrossRef]

31. von der Heidt, T.; Muschter, S.; Caldicott, R.; Che, D. Airbnb in the Byron Shire, Australia-Bane or blessing? Int. J. Tour. Cities 2019, 6, 53-71. [CrossRef]

32. María Martín-Martín, J.; Ostos-Rey, M.S.; Salinas-Fernández, J.A. Why Regulation Is Needed in Emerging Markets in the Tourism Sector. Am. J. Econ. Sociol. 2019, 78, 225-254. [CrossRef]

33. Stabrowski, F. "People as businesses": Airbnb and urban micro-entrepreneurialism in New York City. Camb. J. Reg. Econ. Soc. 2017, 10, 327-347. [CrossRef]

34. Uysal, M.; Sirgy, M.J.; Woo, E.; Kim, H.L. Quality of life (QOL) and well-being research in tourism. Tour. Manag. 2016, 53, 244-261. [CrossRef]

35. Eckert, C.; Pechlaner, H. Alternative product development as strategy towards sustainability in tourism: The case of Lanzarote. Sustainability 2019, 11, 3588. [CrossRef]

36. Democracies in Flux: The Evolution of Social Capital in Contemporary Society; Putnam, R.D. (Ed.) Oxford University Press: Oxford, UK, 2002.

37. Plewnia, F.; Guenther, E. Mapping the sharing economy for sustainability research. Manag. Decis. 2018, 56, 570-583. [CrossRef]

38. Mody, M.; Suess, C.; Dogru, T. Not in my backyard? Is the anti-Airbnb discourse truly warranted? Ann. Tour. Res. 2019, 74, 198-203. [CrossRef]

39. Garau-Vadell, J.B.; Gutiérrez-Taño, D.; Díaz-Armas, R. Residents' Support for P2P Accommodation in Mass Tourism Destinations. J. Travel Res. 2019, 58, 549-565. [CrossRef]

40. Ap, J. Residents' perceptions on tourism impacts. Ann. Tour. Res. 1992, 19, 665-690. [CrossRef]

41. Moscovici, S. Notes towards a description of Social Representations. Eur. J. Soc. Psychol. 1988, 18, $211-250$. [CrossRef] 
42. Valdivielso, J.; Moranta, J. The social construction of the tourism degrowth discourse in the Balearic Islands. J. Sustain. Tour. 2019, 27, 1876-1892. [CrossRef]

43. Doxey, B.G. V When enough's enough: The natives are restless in Old Niagara. Herit. Canada 1976, 2, $26-27$.

44. Butler, R.W. the Concept of a Tourist Area Cycle of Evolution: Implications for Management of Resources. Can. Geogr. Le Géographe Can. 1980, 24, 5-12. [CrossRef]

45. Postma, A.; Schmuecker, D. Understanding and overcoming negative impacts of tourism in city destinations: Conceptual model and strategic framework. J. Tour. Futur. 2017, 3, 144-156. [CrossRef]

46. Görög, G. The Definitions of Sharing Economy: A Systematic Literature Review. Management 2018, 13, 175-189. [CrossRef]

47. Oskam, J.; Boswijk, A. Airbnb: The future of networked hospitality businesses. J. Tour. Futur. 2016, 2, $22-42$. [CrossRef]

48. Netter, S.; Pedersen, E.R.G.; Lüdeke-Freund, F. Sharing economy revisited: Towards a new framework for understanding sharing models. J. Clean. Prod. 2019, 221, 224-233. [CrossRef]

49. Codagnone, C.; Martens, B. Scoping the Sharing Economy Origins, Definitions, Impact and Regulatory Issues. SSRN Electron. J. 2016, 1-36. [CrossRef]

50. Acquier, A.; Daudigeos, T.; Pinkse, J. Promises and paradoxes of the sharing economy: An organizing framework. Technol. Forecast. Soc. Change 2017, 125, 1-10. [CrossRef]

51. Leoni, G.; Parker, L.D. Governance and control of sharing economy platforms: Hosting on Airbnb. Br. Account. Rev. 2019, 51, 100814. [CrossRef]

52. Pawlicz, A. The sharing economy and tourism destination marketing. In The Routledge Handbook of Destination Marketing; Gursoy, D., Chi, C.G., Eds.; Taylor and Francis: Abingdon, UK, 2018; pp. 439-455.

53. Puschmann, T.; Alt, R. Sharing economy. Bus. Inf. Syst. Eng. 2016, 58, 93-99. [CrossRef]

54. Sutherland, W.; Jarrahi, M.H. The sharing economy and digital platforms: A review and research agenda. Int. J. Inf. Manage. 2018, 43, 328-341. [CrossRef]

55. Cantero Gamito, M. Regulation.com. Self-regulation and contract governance in the platform economy: A research agenda. Eur. J. Leg. Stud. 2017, 9, 53-67.

56. Böcker, L.; Meelen, T. Sharing for people, planet or profit? Analysing motivations for intended sharing economy participation. Environ. Innov. Soc. Transit. 2017, 23, 28-39. [CrossRef]

57. Botsman, R.; Rogers, R. What's Mine Is Yours: The Rise of Collaborative Consumption; Harper Collins: New York, NY, USA, 2010.

58. Cohen, B.; Kietzmann, J. Ride On! Mobility Business Models for the Sharing Economy. Organ. Environ. 2014, 27, 279-296. [CrossRef]

59. Belk, R. You are what you can access: Sharing and collaborative consumption online. J. Bus. Res. 2014, 67, 1595-1600. [CrossRef]

60. Cockayne, D.G. Sharing and neoliberal discourse: The economic function of sharing in the digital on-demand economy. Geoforum 2016, 77, 73-82. [CrossRef]

61. Curtis, S.K.; Lehner, M. Defining the sharing economy for sustainability. Sustainability 2019, 11, 567. [CrossRef]

62. Demailly, D.; Novel, A.-S. The sharing economy: Make it sustainable. Studies 2014, 3, 1-30.

63. Frenken, K. Political economies and environmental futures for the sharing economy. Philos. Trans. R. Soc. A Math. Phys. Eng. Sci. 2017, 375, 20160367. [CrossRef]

64. Tussyadiah, I.P.; Pesonen, J. Impacts of Peer-to-Peer Accommodation Use on Travel Patterns. J. Travel Res. 2016, 55, 1022-1040. [CrossRef]

65. Geissinger, A.; Laurell, C.; Sandström, C. Digital Disruption beyond Uber and Airbnb-Tracking the long tail of the sharing economy. Technol. Forecast. Soc. Change 2018, 119323. [CrossRef]

66. Hjalager, A.M. Stages in the economic globalization of tourism. Ann. Tour. Res. 2007, 34, 437-457. [CrossRef]

67. Palmer, N.J. Economic and transition and the struggle for local control in ecotourism development: The case of Kyrgyzstan. J. Ecotourism 2006, 5, 40-61. [CrossRef]

68. Milne, S.; Ateljevic, I. Tourism, economic development and the global-local nexus: Theory embracing complexity. Tour. Geogr. An Int. J. Tour. Space, Place Environ. T 2001, 3, 369-393. [CrossRef]

69. Cocola-Gant, A.; Gago, A. Airbnb, buy-to-let investment and tourism-driven displacement: A case study in Lisbon. Environ. Plan. A 2019. [CrossRef] 
70. Voytenko Palgan, Y.; Zvolska, L.; Mont, O. Sustainability framings of accommodation sharing. Environ. Innov. Soc. Transitions 2017, 23, 70-83. [CrossRef]

71. Guttentag, D. Transformative experiences via Airbnb: Is it the guests or the host communities that will be transformed? J. Tour. Futur. 2019, 5, 179-184. [CrossRef]

72. Habibi, M.R.; Davidson, A.; Laroche, M. What managers should know about the sharing economy. Bus. Horiz. 2017, 60, 113-121. [CrossRef]

73. Roelofsen, M. Exploring the socio-spatial inequalities of Airbnb in Sofia, Bulgaria. Erdkunde 2018, 72, $313-327$. [CrossRef]

74. Dodds, R.; Butler, R. The phenomena of overtourism: A review. Int. J. Tour. Cities 2019, 5, 519-528. [CrossRef]

75. Kruczek, Z. Turyści vs. mieszkańcy. Wpływ nadmiernej frekwencji turystów na proces gentryfikacji miast historycznych na przykładzie Krakowa. Tur. Kult. 2018, 2018, 29-41.

76. Milano, C.; Cheer, J.M.; Novelli, M. Overtourism is becoming a major issue for cities across the globe. Available online: https://www.weforum.org/agenda/2018/07/overtourism-a-growing-global-problem (accessed on 13 February 2019).

77. Goodwin, H. The Challenge of Overtourism. Responsible Tourism Partnership Working Paper 4. October 2017. Available online: https://haroldgoodwin.info/pubs/RTP\%27WP4Overtourism01\%272017.pdf (accessed on 15 March 2010).

78. Dodds, R.; Butler, R.W. Introduction. In Overtourism: Issues, Realities and Solutions and Solutions; Dodds, R., Butler, R.W., Eds.; De Gruyter: Berlin, Germany, 2019; pp. 1-5.

79. Zmyślony, P.; Kowalczyk-Anioł, J. Urban tourism hypertrophy: Who should deal with it? The case of Krakow (Poland). Int. J. Tour. Cities 2019, 5, 247-269. [CrossRef]

80. Fletcher, R.; Murray Mas, I.; Blanco-Romero, A.; Blázquez-Salom, M. Tourism and degrowth: An emerging agenda for research and praxis. J. Sustain. Tour. 2019, 27, 1745-1763. [CrossRef]

81. Blázquez-Salom, M.; Blanco-Romero, A.; Vera-Rebollo, F.; Ivars-Baidal, J. Territorial tourism planning in Spain: From boosterism to tourism degrowth? J. Sustain. Tour. 2019, 27, 1764-1785. [CrossRef]

82. Naisbitt, J. Megatrends: Ten Mew Directions Transforming Our Lives; Futura Publications: New York, NY, USA, 1982.

83. Alejziak, W. A Global Tourism Policy-Utopia, Alternative or Necessity? Folia Tur. 2011, 25, 313-356.

84. Alejziak, W.; Szczechowicz, B. Globalizacja a rozwój turystyki-Implikacje dla planowania i polityki turystycznej. In Uwarunkowania i Plany Rozwoju Turystyki. Turystyka Przyrodnicza i Uwarunkowania jej Rozwoju. Turystyka i Rekreacja—Studia i Prace; Młynarczyk, Z., Zajadacz, A., Eds.; Bogucki Wydawnictwo Naukowe: Poznan, Poland, 2018; Volume 22, pp. 9-26.

85. Bouchon, F.; Rauscher, M. Cities and tourism, a love and hate story; towards a conceptual framework for urban overtourism management. Int. J. Tour. Cities 2019, 5, 598-619. [CrossRef]

86. Calzada, I. Local entrepreneurship through a multistakeholders' tourism living lab in the post-violence/peripheral era in the Basque Country. Reg. Sci. Policy Pract. 2019, 11, 451-466. [CrossRef]

87. Sarantakou, E.; Terkenli, T.S. Non-Institutionalized Forms of Tourism Accommodation and Overtourism Impacts on the Landscape: The Case of Santorini, Greece. Tour. Plan. Dev. 2019, 16, 411-433. [CrossRef]

88. Dodds, R.; Butler, R.W. The enablers of overtourism. In Overtourism: Issues, Realities and Solutions; Dodds, R., Butler, R.W., Eds.; De Gruyter: Berlin, Germany, 2019; pp. 6-21.

89. Gyódi, K. Airbnb in European cities: Business as usual or true sharing economy? J. Clean. Prod. 2019, 221, 536-551. [CrossRef]

90. Oskam, J. The Future of Airbnb and the Sharing Economy: The Collaborative Consumption of Our Cities; Channel View Publication: Bristol, UK, 2019.

91. Smith, M.K.; Sziva, I.P.; Olt, G. Overtourism and Resident Resistance in Budapest. Tour. Plan. Dev. 2019, 16, 376-392. [CrossRef]

92. Novy, J.; Colomb, C. Urban tourism and its discontents. In Protest and Resitance in the Tourist City; Colomb, C., Novy, J., Eds.; Routledge: Oxon, Lithuania, 2017; pp. 1-30.

93. Mawhinney, M. Sustainable Development: Understanding the Green Debates; Blackwell Science: Oxford, UK, 2002.

94. Butler, R.W. Le tourisme durable: Un état de la question. Tour. Geogr. 1999, 1, 7-25. [CrossRef]

95. Jovicic, D.Z. Key issues in the implementation of sustainable tourism. Curr. Issues Tour. 2014, 17, $297-302$. [CrossRef] 
96. Szromek, A.R.; Kruczek, Z.; Walas, B. The Attitude of Tourist Destination Residents towards the Effects of Overtourism-Krakow Case Study. Sustainability 2020, 12, 228. [CrossRef]

97. Fukuyama, F. Social capital, civil society and development. Third World Q. 2001, 22, 7-20. [CrossRef]

98. Bourdieu, P.; Wacquant, L.J.D. An Invitation to Reflexive Sociology; University of Chicago Press: Chicago, IL, USA, 1992.

99. Fukuyama, F. Social Capital and Civil Society. In Proceedings of the International Monetary Fund Conference on Second Generation Reforms, Washington, DC, USA, 8-9 November 1999.

100. Stankiewicz, E. Kapitał społeczny w perspektywie interdyscyplinarnej. Kwart. Prawo-Społeczeństwo-Ekon. 2016, 4, 44-65.

101. Quibria, M.G. The puzzle of social capital: A critical review. Asian Dev. Rev. 2003, 20, 19-39.

102. Adler, P.S.; Kwon, S.W. Social capital: Prospects for a new concept. Acad. Manag. Rev. 2002, 27, 17-40. [CrossRef]

103. Rodriguez-Giron, S.; Vanneste, D. Social capital at the tourist destination level: Determining the dimensions to assess and improve collective action in tourism. Tour. Stud. 2019, 19, 23-42. [CrossRef]

104. Harper, R. Social Capital: A Review of the Literature; Social Analysis and Reporting Division; Office for National Statistics: London, UK, 2001.

105. Patulny, R.V.; Lind Haase Svendsen, G. Exploring the social capital grid: Bonding, bridging, qualitative, quantitative. Int. J. Sociol. Soc. Policy 2007, 27, 32-51. [CrossRef]

106. Hawkins, R.L.; Maurer, K. Bonding, bridging and linking: How social capital operated in New Orleans following Hurricane Katrina. Br. J. Soc. Work 2010, 40, 1777-1793. [CrossRef]

107. Claridge, T. Functions of social capital-Bonding, bridging, linking. Soc. Cap. Res. 2018, 1-7.

108. Bryant, C.-A.; Norris, D. Measurement of Social Capital: The Canadian Experience. In Proceedings of the Country report for the OECD-UK ONS International Conference on Social Capital Measurement in London, London, UK, 25-27 September 2002; pp. 25-27.

109. Zmerli, S. Applying the concepts of bonding and bridging social capital to empirical research. Eur. Polit. Sci. 2003, 2, 68-75. [CrossRef]

110. Weaver, R.D.; McMurphy, S.M.; Habibov, N.N. Analyzing the Impact of Bonding and Bridging Social Capital on Economic Well-Being: Results from Canada's General Social Survey. Sociol. Spectr. 2013, 33, 566-583. [CrossRef]

111. Haynes, P. Before Going Any Further With Social Capital: Eight Key Criticisms to Address. INGENIO Work. Pap. Ser. 2009, 2009, 1-23.

112. Heinrichs, H. Sharing Economy: A Potential New Pathway to Sustainability. GAIA Ecol. Perspect. Sci. Soc. 2013, 22, 228-231. [CrossRef]

113. Dillahunt, T.R.; Malone, A.R. The Promise of the Sharing Economy among Disadvantaged Communities. In Proceedings of the CHI 2015, Seoul, Korea, 18-23 April 2015.

114. Crescenzi, R.; Gagliardi, L.; Percoco, M. The 'Bright' side of social capital: How 'Bridging' makes Italian provinces more innovative. Adv. Spat. Sci. 2013, 76, 143-164.

115. Eklinder-Frick, J.; Eriksson, L.T.; Hallén, L. Bridging and bonding forms of social capital in a regional strategic network. Ind. Mark. Manag. 2011, 40, 994-1003. [CrossRef]

116. Eklinder-Frick, J.; Eriksson, L.T.; Hallén, L. Effects of social capital on processes in a regional strategic network. Ind. Mark. Manag. 2012, 41, 800-806. [CrossRef]

117. Bhandari, H.; Yasunobu, K. What is social capital? A comprehensive review of the concept. Asian J. Soc. Sci. 2009, 37, 480-510. [CrossRef]

118. Trigilia, C. Social Capital and Local Development. Eur. J. Soc. Theory 2001, 4, 427-442. [CrossRef]

119. Woolcock, M.; Narayan, D. Social Capital: Implications for Development Theory, Research, and Policy. World Bank Res. Obs. 2000, 15, 225-249. [CrossRef]

120. Politics, Trust and Networks: Social Capital in Critical Perspective; Franklin, J. (Ed.) London South Bank University: London, UK, 2004.

121. Myeong, S.; Seo, H. Which type of social capital matters for building trust in government? Looking for a new type of social capital in the governance era. Sustainability 2016, 8, 322. [CrossRef]

122. Zhang, S.; Anderson, S.G.; Zhan, M. The differentiated impact of bridging and bonding social capital on economic well-being: An individual level perspective. J. Sociol. Soc. Welf. 2011, 38, 119-142. 
123. Soulard, J.; Knollenberg, W.; Boley, B.B.; Perdue, R.R.; McGehee, N.G. Social capital and destination strategic planning. Tour. Manag. 2018, 69, 189-200. [CrossRef]

124. Moscardo, G. Building community capacity for tourism development. Build. Community Capacit. Tour. Dev. 2008, 36, 1-184.

125. Nasser, W. Regional tourism competitiveness. In Knowledge Management in Tourism: Policy and Governance Applications (Bridging Tourism Theory and Practice); Fayos-solà, E., Ed.; Emerald Group Publishing Limited: Bingley, UK, 2012; Volume 4, pp. 77-94.

126. Zhao, J.; Peng, Z. Shared short-term rentals for sustainable tourism in the social-network age: The impact of online reviews on users' purchase decisions. Sustainability 2019, 11, 4064. [CrossRef]

127. Zuleta Ferrari, M. Beyond uncertainties in the sharing economy: Opportunities for social capital. Eur. J. Risk Regul. 2016, 7, 664-674. [CrossRef]

128. Marsden, P. The 10 Business Models of Digital Disruption (and How to Respond to Them). Available online: https://digitalwellbeing.org/the-10-business-models-of-digital-disruption-and-how-to-respond-tothem/ (accessed on 26 August 2015).

129. Putnam, R.D. Bowling Alone: The Collapse and Revival of American Community; Simon \& Schuster: New York, NY, USA, 2001.

130. Schindler, J. Autoteliczność i instrumentalność kapitału społecznego. Zoon Polit. 2015, 6, 61-87.

(C) 2020 by the authors. Licensee MDPI, Basel, Switzerland. This article is an open access article distributed under the terms and conditions of the Creative Commons Attribution (CC BY) license (http://creativecommons.org/licenses/by/4.0/). 